\title{
Analysing Existence of Volatility Persistence in Sub-Sahara Africa Stock Markets
}

\author{
Peter Ifeanyichukwu Ali \\ Department of Financial Management Technology Federal University of Technology \\ P.M.B. 1526, Owerri Imo State-Nigeria
}

\section{Info Article}

Keywords:

GARCH Model; Stock Market

Returns; Sub-Sahara Africa;

Volatility Persistence

\begin{abstract}
Abtract
The aim of this paper was to analyse volatility persistence in Sub-Sahara stock markets. The study concentrated on selected markets including Ghana, Nigeria and South Africa by analysing univariate GARCH $(1,1)$ model using monthly data from January 2000 to December 2017. Estimates from descriptive statistics show that the mean monthly returns are positive for the Sub-Sahara stock markets, but the South Africa stock market generates more returns than Nigeria and Ghana within the study period. Skewness coefficients show that the stock returns distributions of the Sub-Sahara Africa stock markets are negatively skewed. Excess kurtosis is positive for all the stock markets returns. The Jarque-Bera statistics indicate the stock markets' series are not normally distributed. Unit roots tests results indicate that the Sub-Sahara Africa stock markets series are integrated of order one. The results of the GARCH $(1,1)$ model provide evidence to show that the Sub-Sahara Africa stock markets exhibit volatility clustering and persistence. The study therefore concludes that there is volatility persistence in Sub-Sahara Africa Stock Markets. The study therefore recommends that Sub-Sahara Africa portfolio managers watch movements in stock market volatility as part of their portfolio management strategy and formulate cushion policies to mitigate effects of volatility shocks.
\end{abstract}

Citation: Ali, Ifeanyichukwu Peter. (2019). Analysing Existence of Volatility Persistence in Sub-Sahara Africa Stock Markets. AFRE Accounting and Financial Review, $2(1)$

ISSN (online): 2598-7771

\footnotetext{
$\triangle$ Corresponding Author:

Peter Iffeanyichukwu Ali

Telp. /Fax. -

E-mail: frpeterali@yahoo.com
}

JEL Classification G10, O55

DOI: https://doi.org/10.26905/afr.v2i1.3263

\section{INTRODUCTION}

There exists a consensus in the financial literature that stock returns volatility affects the overall health of the economy (Schwert, 1989; Chowdhury et al, 2006). Volatility breeds uncertainty which hampers the growth of the entire economy. An unexpected increase in volatility today, according to Emenike (2014), results in upward revision of future expectation of volatility and risk premium which in turn leads to the discounting of future expected cash flows at an increased rate which leads to lower stock returns today. Understanding the nature of volatility of stock market return has numerous applications in managing investment portfolio, pricing of options, risk management and financial market regulation (Poon \& Granger, 2003; Granger, 2003).
Hence the interrelationship between changes in macroeconomic variables and stock market return volatility is useful for investors to make necessary investment decisions and for policy-makers to regulate financial markets more effectively.

Many empirical studies have analysed the nature of volatility clustering in both developing and developed markets using GARCH models (see for example, Emenike, 2010; Ahmed and Suliman, 2011; Makhwiting, Lesaoana and Sigauke, 2012; Anjikwi \& Danjuma, 2018). Ahmed and Suliman (2011) for example modeled stock market volatility using the Generalized Autoregressive Conditional Heteroscedastic (GARCH) models to examine evidence of volatility clustering in the daily returns of the Khartoum Stock Exchange (KSE) Sudan over the period from January 2006 to November 2010. They report- 
ed evidence of volatility clustering and persistence in Khartoum Stock Exchange. Makhwiting, Lesaoana and Sigauke (2012) also applied GARCH models to investigate volatility and financial market risk of stocks in the Johannesburg Stock Exchange (JSE) assuming skewed Student-t distribution. However, these studies are country-specific studies that examine stock market volatility in specific countries. There is need for comparative evidence on the nature of stock market volatility in Sub Saharan Africa.

The aim of this paper is to analyse the nature of volatility clustering on one hand and volatility persistence of stock market returns of Nigeria, Ghana and South Africa on the other hand. The analysis will not only be useful to portfolio investment management and risk management but also to financial market regulation in Sub-Sahara Africa. The portfolio managers for instance, will have evidence on the behaviour of stock return volatility in Sub-Sahara Africa as well how volatility respond to positive and negative stock market information. Such information will assist in evidence-based portfolio selection and management. Scholars will equally find this paper useful as it will serve as reference material for future research

\section{REVIEW OF RELATED LITERATURE}

One of the earliest studies on volatility was Engle (1982) which propounded the autoregressive conditional heteroscedasticity $(\mathrm{ARCH})$ model to evaluate volatility by relating the conditional variance of the error term to the linear combination of the squared error terms in the recent past. Bollerslev (1986) generalized the ARCH model including the conditional variance to depend on its lagged values as well as squared lagged values of the error terms, as a result of the long lag length and large parameters needed to estimate ARCH model. After the premier ARCH paper of Engle (1982) and the generalization of ARCH model by Bollerslev (1986), the study of volatility has gained major attention from policy makers, practitioners and researchers.

Okpara and Nwezeaku (2009) examined the impact of idiosyncratic risk and beta risk on stock returns of 41 quoted companies selected randomly from Nigerian Stock Exchange for the study period ranging from 1996 to 2005. The study adopted a two-step estimation procedures in which the time series procedure was used on the data to determine the beta and idiosyncratic risk for each of the companies; and a cross-sectional estimation procedure of EGARCH $(1,3)$ model was adopted to establish the effect of both the idiosyncratic risk and beta risk on the stock market returns. The results show, amongst others, that volatility clustering is not quite persistent but there exists asymmetric effect in the Nigerian stock market. They concluded that unexpected bad news increases predictable volatility more than good news of similar magnitude in Nigeria.

Emenike (2010) used monthly All Share Index (ASI) from January, 1985 to December, 2008 as an empirical sample to investigate stock return volatility clustering and persistence in the Nigerian stock exchange market using GARCH $(1,1)$ model. The overall results indicate evidence of volatility clustering; fat-tailed distribution and the existence persistence in the Nigerian stock exchange market return series.

Ahmed and Suliman (2011) Modeled volatility of stock market using the GARCH model to examine whether there is volatility clustering and persistence in the daily returns of the Khartoum Stock Exchange Sudan for the January 2006 to November 2010 period. Findings obtained from the study suggest that there is evidence of volatility clustering and persistence. They conclude that the Sudanese stock market exhibit volatility clustering and persistence over the sample period.

Makhwiting, Lesaoana and Sigauke (2012) adapted autoregressive moving average (ARMA) GARCH models to investigate volatility and financial market risk of stocks in the Johannesburg Stock Exchange (JSE) assuming skewed Student-t distribution. They used daily data for the period starting from 2002 to 2010. They estimated several types of GARCH models namely threshold GARCH, GARCH-in mean and exponential GARCH. Their findings show that JSE daily returns can be modeled using an ARMA $(0,1)$ process. This implies that shocks to conditional mean disappear after one period. The results further show that ARMA $(0,1)$ GARCH $(1,1)$ model achieves the most accurate volatility forecast. Emenike and Aleke (2012) examined the volatility of Nigerian stock exchange market for the presence of asymmetric effect using daily closing prices of the weighted All Share Index from January 2, 1996 to December 30, 2012, they employed GARCH $(1,1)$, EGARCH and GJR-GARCH model and report volatility clustering, and high volatility persistence in the Nigerian stock exchange market (NSE). They also report the presence of asymmetric effect in the NSE return series.

A more recent study by Anjikwi \& Danjuma (2018) analyzed volatility in Nigeria stock market using Bayesian approach in stochastic volatility 
model. The sample data used for this study were daily and weekly closing prices of All Share Index over the period of January 30th, 2012 to December 8th, 2016. The findings show amongst others that there is volatility and persistence in Nigeria stock returns. From the brief review of empirical literature presented above, it is clear that African stock market returns exhibit volatility clustering and persistence behaviour.

\section{DATA AND METHODS}

\section{Description of Data}

The data for this study were generated from secondary sources. The data consisted of Monthly All-Share Index (ASI) of the Nigerian Stock Exchange (NSE), the Ghanaian Stock Exchange (GSE) and the Johannesburg Stock Exchange (JSE). These series were transformed into the first difference of natural logarithm of prices or indices thus:

$\mathrm{R}_{\mathrm{t}}=\operatorname{Ln}\left(\mathrm{P}_{\mathrm{t}}-\mathrm{P}_{\mathrm{t}-1}\right)$

Where: $R_{t}=$ monthly returns of the Sub-Sahara African stock market returns, $P_{t}=$ closing monthly stock indices at time $t, P_{t-1}=$ previous month closing stock indices, and $L n=$ natural logarithm.

\section{Method of Data Analysis}

To examine volatility clustering on the Nigeria, Ghana, and South Africa Stock market returns, the GARCH $(1,1)$ was used. This is in agreement with earlier studies of volatility clustering (see for example, Brook and Burke, 2003). The GARCH $(1,1)$ is a parametric test developed to examine whether an observed sequence has a GARCH feature or not. Positive slope coefficient suggest that if volatility was high in the previous period, it will continue be high in the current period, thus indicating volatility clustering. Zero coefficient; on the other hand, indicate evidence against volatility (Gujarati, 2003: 858). Volatility persistence on the other hand was measured using the sum of the ARCH and GARCH parameters. The GARCH $(1,1)$ modeling process involves two steps. The first step involves specifying a model for the mean return series and the second step involves modeling the conditional variance of the residuals (Emenike, 2010). The GARCH $(1,1)$ was specified as follow:

$$
\begin{aligned}
& \mathrm{R}_{\mathrm{t}}=\theta+\mu_{\mathrm{t}} \ldots \ldots \ldots \ldots \ldots \ldots \\
& \mu_{\mathrm{t}} \sim\left(0,6^{2}\right) \\
& 6^{2}{ }_{\mathrm{t}}=\mathrm{a}_{0}+\mathrm{a}_{1} \mu^{2}{ }_{\mathrm{t}-1}+\beta_{1} 6^{2}{ }_{\mathrm{t}-1}
\end{aligned}
$$

Where, $R_{t}$ is the mean return equation, $\theta$ is a constant $\mu_{\mathrm{t}}$ is the error term or residual. The $6^{2}{ }_{\mathrm{t}}$ is the conditional variance equation (i.e. the volatility at time $t), a_{0}$ is the constant, $a_{1}$ is first order $\mathrm{ARCH}$ term, and $\beta_{1}$ is first order GARCH term (i.e., clustering coefficient). The conditional variance equation (3.3) postulates that volatility in the current period (i.e. month $t$ ) is not only related to the squared error term in the previous term but also on its conditional variance in the previous time period (i.e. month $t-1$ ). Under the null hypothesis of no GARCH effects (i.e. no volatility clustering in the Sub-Saharan African return series), all slope coefficients are zero. The robustness of the GRACH $(1,1)$ model was evaluated using the non-negativity constraints as well as the Ljung-Box $Q$ statistic and ARCH-LM test (Enders, 2004: 136; Engle \& Paton, 2001).

\section{RESULT}

\section{Descriptive Statistics of Stock Market Indexes in Sub-Sahara Africa}

Table 1 shows the descriptive statistics of the level and return series of the monthly All-share index for Sub-Sahara Africa stock markets. As shown in Table 1, the average monthly All-share index for Nigeria is 26625, Ghana is 3481 and South Africa is 28218. The average monthly return for Nigeria, Ghana and South Africa are 0.008, 0.005 and 0.009 respectively, for the study period. These results indicate that the South Africa stock market generates more returns than Nigeria and Ghana; and Nigeria stock market generates more returns than the Ghana stock market within the study period. The corresponding monthly standard deviations are 0.069, 0.144 , and 0.047. These indicate that Ghana stock market has the highest rate of variability from the mean return, whereas the South Africa stock market has the least variability from its mean. The null hypothesis of normal distribution of Jarque-Bera statistics is 0 . The empirical Jarque-Bera statistics for all the variables deviate from normal distribution at the $5 \%$ significance level. Similarly, skewness and kurtosis represent the nature of departure from normality. In a normally distributed series, skewness is 0 and kurtosis is 3. Positive or negative skewness indicate asymmetry in the time series under study and kurtosis coefficient greater than or less than 3 suggest peakedness or flatness of the data (Gujarati, 2003; Emenike, 2016). The skewness coefficient for Nigeria, Ghana and South Africa Stock markets are $0.577,--11.318$, and -0.278 , respectively. These indicate that the Sub-Saharan African stock markets returns are negatively skewed; thus implying that there are more negative changes in the Sub-Saharan African stock markets returns than predicted by 
normal distribution. The kurtosis coefficients for all the Sub-Saharan African stock markets returns series show evidence of peaked distribution. The implication of peaked is that, for a large part of the time, extreme observations are much more likely to occur. Leptokurtic stock returns, for example, implies that investors can make very high returns and as well lose large amount of their investments (Wilcox and Keselman, 2003).

Table 1. Descriptive Statistics for Sub-Saharan African Stock Markets Indexes

\begin{tabular}{llllll}
\hline $\begin{array}{l}\text { Vari- } \\
\text { able }\end{array}$ & Mean & Std. Dev. & $\begin{array}{l}\text { Skew- } \\
\text { ness }\end{array}$ & $\begin{array}{l}\text { Kurto- } \\
\text { sis }\end{array}$ & J-B Stat. \\
\hline NSI & 26625.47 & 12291.14 & 0.664 & 0.552 & 18.649 \\
GSI & 3481.28 & 2678.75 & 0.999 & 0.088 & 36.006 \\
SASI & 28218.30 & 16029.13 & 0.308 & -1.204 & 16.469 \\
& \multicolumn{7}{c}{ Return Series } \\
NSI & 0.008 & 0.069 & -0.577 & 5.520 & 284.926 \\
& & $0.0 .000)$ & $(0.000)$ & $(0.000)$ \\
GSI & 0.005 & 0.144 & -11.318 & 151.42( & 209993.18 \\
& & & $(0.000)$ & $0.000)$ & $(0.000)$ \\
SASI & 0.009 & 0.047 & -0.278 & 0.655 & 6.623 \\
& & & $(0.098)$ & $(0.053)$ & $(0.036)$ \\
\hline
\end{tabular}

Note: $P$-values are displayed as (.). All the tests are conducted at $5 \%$ significant level

\section{Time Series Graphs of Stock Market Indexes in} Sub-Sahara Africa

Figures 1, 2 and 3 present graphs of the loglevels and returns series of the All-share index for Nigeria, Ghana and South Africa for the study peri- od. Notice from Figure 1, that the log-level series is trending whereas return series appear to be mean reverting. This implies that the log-level series may not be stationary whereas the differenced series appear stationary. Notice also large downward and upward spike in the 2008 and 2009 period, which correspond with the era of the global financial crisis. Again notice the Nigeria stock return series regained its upward movement after the global financial crisis. From the last quarter of 2016, the series started moving towards a new upward level.

Observe from the Ghana stock market series in Figure 2 that there is one major spike between the large quarter of 2010 and first quarter of 2011. This corresponds to the period the GSE introduced a new methodology for computing daily closing prices of equities on the bourse in January 2011. Two new indices were also introduced on January 4, 2011 to replace the GSE All-Share Index which tracks price changes in the listed equities. The new indices were the GSE Composite Index and the GSE Financial Stocks Index.

From Figure 3, notice that the log-level series has a smooth trend during the sample period except for the first quarter of 2003 and 2008/2009 global financial crisis. The return series on the other hand appear to be mean reverting. This implies that the log-level series may not be stationary whereas the differenced series appear stationary.

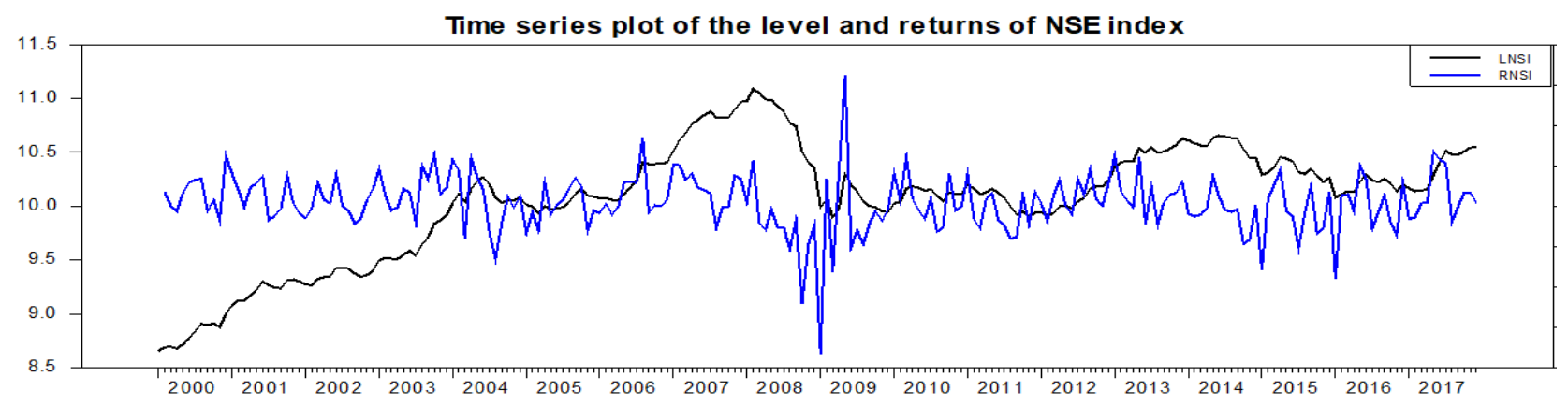

Figure 1. Time Graph of Level and Returns for Stock Market Index in Nigeria January 2000 to December 2017

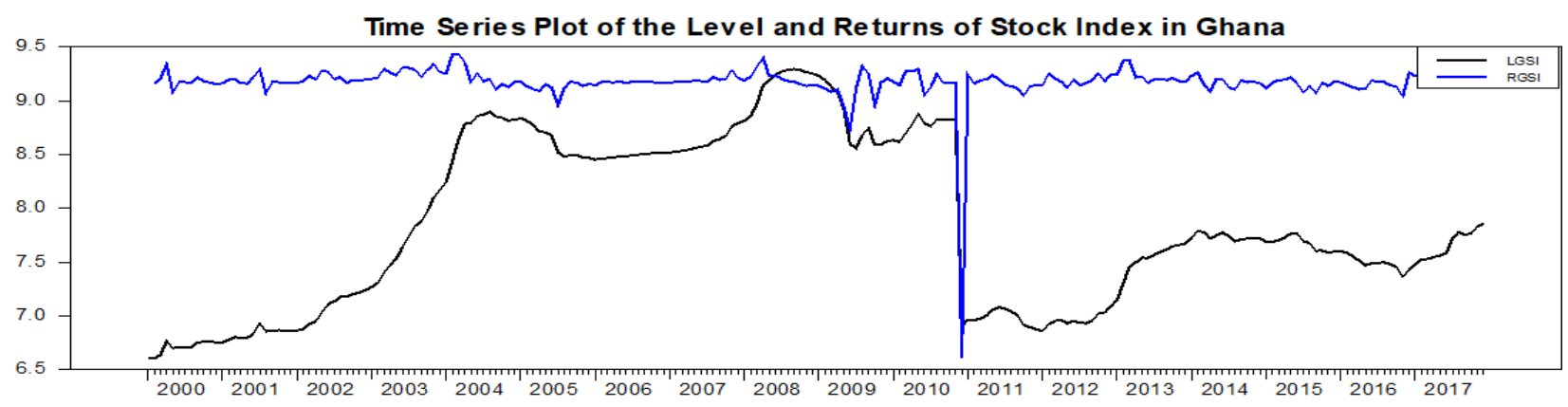

Figure 2. Time Graph of Level and Returns for Stock Market Index in Ghana January 2000 to December 2017 


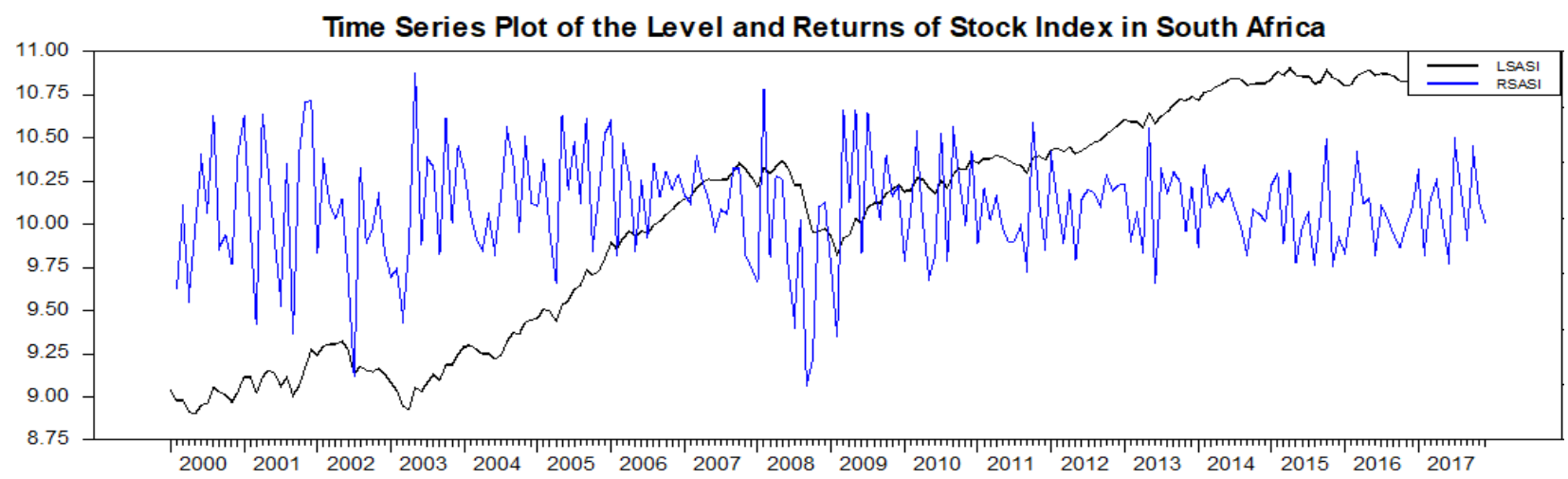

Figure 3. Time graph of level and returns for stock market index in South Africa January 2000 to December 2017

\section{Unit Roots Tests for Stock Market Indexes in Sub-Sahara Africa}

This sub-section presents the unit roots tests conducted to examine the stock market indexes for stationarity. Table 2 presents the result of unit roots tests for the log-levels and first difference series of the stock market indices for Nigeria, Ghana and South Africa. The unit roots tests were computed using augmented Dickey-Fuller (ADF) (Dickey \& Fuller, 1981) and Phillips-Perron (PP) tests. The ADF and PP tests were computed at the 5\% level of significance in order not to accept a false null hypothesis.

Table 2. Unit Root Tests Results for Sub-Saharan African Stock Markets Indexes

\begin{tabular}{|c|c|c|c|c|}
\hline \multirow[b]{3}{*}{ Variables } & \multicolumn{4}{|c|}{ ADF Unit Root Test Results } \\
\hline & \multicolumn{2}{|c|}{ Log-level series } & \multicolumn{2}{|c|}{ Return series } \\
\hline & $\begin{array}{l}\text { critical } \\
\text { value 5\% }\end{array}$ & $\begin{array}{l}\text { computed } \\
\text { value }\end{array}$ & $\begin{array}{l}\text { critical } \\
\text { value 5\% }\end{array}$ & $\begin{array}{l}\text { computed } \\
\text { value }\end{array}$ \\
\hline NSI & -2.875 & -2.540 & -2.875 & $-12.299 * *$ \\
\hline GSI & -2.874 & -1.820 & -2.875 & $-13.682^{* *}$ \\
\hline SASI & -2.874 & -0.678 & -2.875 & $-15.287^{* *}$ \\
\hline Variables & $\begin{array}{l}\text { Phillips- } \\
\text { critical } \\
\text { value 5\% }\end{array}$ & $\begin{array}{l}\text { con Unit Ror } \\
\text { computed } \\
\text { value }\end{array}$ & $\begin{array}{l}\text { Test Resu } \\
\text { critical } \\
\text { value 5\% }\end{array}$ & $\begin{array}{l}\text { computed } \\
\text { value }\end{array}$ \\
\hline NSI & -2.874 & -2.571 & -2.875 & $-12.524^{* *}$ \\
\hline GSI & -2.874 & -1.919 & -2.875 & $-13.786^{* *}$ \\
\hline SASI & -2.874 & -0.694 & -2.875 & $-15.337^{* *}$ \\
\hline
\end{tabular}

Notice from Table 2 that the Nigeria, Ghana and South Africa stock markets level series are not stationary. This is because the absolute computed ADF values for Nigeria (-2.54), Ghana (-1.82) and South Africa (-0.67) are less than the 5\% ADF critical tau value (-2.87). The PP tests show similar results for all the stock markets studied. In their first differences, however, the absolute values of the computed ADF coefficients exceed the critical values at $5 \%$ significance level. Table 2 shows that the computed ADF coefficient -12.29, -13.68, and -15.28 for the Nigeria, Ghana and South Africa stock markets returns are greater than the theoretical value ($2.87)$ at $5 \%$ significance level.

Table 3. Results of GARCH $(1,1)$ Model for Sub-Sahara Stock Markets Returns

\begin{tabular}{|c|c|c|c|}
\hline \multirow[t]{2}{*}{ Parameters } & \multicolumn{3}{|c|}{ Coefficients } \\
\hline & Nigeria & Ghana & South Africa \\
\hline Mean & $\begin{array}{l}0.013 \\
(2997)\end{array}$ & 0.0127 & $\begin{array}{l}0.012 \\
(4.326)\end{array}$ \\
\hline RSI $\{1\}$ & $\begin{array}{l}0.171 \\
(2.109)\end{array}$ & - & $\begin{array}{l}-0.105 \\
(-1.503)\end{array}$ \\
\hline Constant $\left(\mathrm{a}_{0}\right)$ & $\begin{array}{l}0.000 \\
(2.098)\end{array}$ & $\begin{array}{l}0.016 \\
(5.480)\end{array}$ & $\begin{array}{l}0.000 \\
(1.203)\end{array}$ \\
\hline $\mathrm{ARCH}\left(\mathrm{a}_{1}\right)$ & $\begin{array}{l}0.166 \\
(2.607)\end{array}$ & $\begin{array}{l}0.227 \\
(8.903)\end{array}$ & $\begin{array}{l}0.207 \\
(2.456)\end{array}$ \\
\hline GARCH $\left(\beta_{1}\right)$ & $\begin{array}{l}0.718 \\
(8.965)\end{array}$ & $\begin{array}{l}0.694 \\
(16.258)\end{array}$ & $\begin{array}{l}0.762 \\
(9.006)\end{array}$ \\
\hline$\left(\alpha_{1}+\beta_{1}\right)$ & 0.884 & 0.921 & 0.969 \\
\hline \multicolumn{4}{|c|}{$\begin{array}{r}\text { Panel B: Diagnostic Tests } \\
\text { Statistic }\end{array}$} \\
\hline & Nigeria & Ghana & South Africa \\
\hline $\begin{array}{l}\text { Ljung-Box Q } \\
\text { (2) }\end{array}$ & $\begin{array}{l}2.429 \\
(0.296)\end{array}$ & $\begin{array}{l}10.906 \\
(0.240)\end{array}$ & $\begin{array}{l}0.338 \\
(0.844)\end{array}$ \\
\hline $\begin{array}{l}\text { Ljung-Box Q } \\
\text { (12) }\end{array}$ & $\begin{array}{l}20.689 \\
(0.155)\end{array}$ & $\begin{array}{l}31.725 \\
(0.091)\end{array}$ & $\begin{array}{l}6.101 \\
(0.910)\end{array}$ \\
\hline $\begin{array}{l}\text { ARCH-LM } \\
\text { (6) }\end{array}$ & $\begin{array}{l}7.174 \\
(0.304)\end{array}$ & $\begin{array}{l}14.814 \\
(0.201)\end{array}$ & $\begin{array}{l}3.639 \\
(0.725)\end{array}$ \\
\hline
\end{tabular}

\section{GARCH $(1,1)$ Results for Nigeria Stock Market Returns Volatility}

Table 3 presents the results of GARCH $(1,1)$ model estimated to evaluate volatility clustering and persistence in the Sub-Sahara Africa stock markets returns. Notice from Table 2 that the coefficient for long-run average volatility $\left(\mathrm{a}_{0}\right)$ is significant at 5\% significant level for the Nigeria and Ghana stock markets, suggesting that volatility of stock returns in the past periods influence current volatility in both Nigeria and Ghana stock market but not for South Africa stock market. The coefficient of ARCH parameter $\left(a_{1}\right)$ is significant at the $5 \%$ level for the Nigeria and Ghana and South Africa stock markets, indicating that the volatility of 
stock returns in the previous periods influence current volatility in Sub-Sahara Africa stock markets. The coefficient of GARCH parameter $\left(\beta_{1}\right)$ is also statistically significant at the $5 \%$ level, thus indicate evidence of volatility clustering in the Sub-Sahara Africa stock markets returns. The persistence parameter $\left(\alpha_{1}+\beta_{1}\right)$ also indicate evidence of volatility persistence in the Sub-Sahara Africa stock markets returns. This is because the persistence parameter tends to unity in all the Sub-Sahara Africa stock markets examined.

\section{DISCUSSION}

The finding of significant volatility clustering in Nigeria stock market returns has support in empirical literature. For example, Okpara and Nwezeaku (2009) show, among others, that there is existence of volatility clustering in the Nigerian stock market when examined the effect of the idiosyncratic risk and beta risk on the returns of the 41 randomly selected companies listed in the Nigerian stock exchange from 1996 to 2005. Similar finding was documented by Emenike and Aleke (2012) who examined the volatility of Nigerian stock exchange market for the existence of volatility clustering using daily closing prices of the weighted All Share Index from January 2, 1996 to December 30, 2012. They documented evidence of volatility clustering and high volatility persistence in the Nigerian stock exchange market (NSE). They also report the presence of asymmetric effect in the NSE return series. Similarly, the finding of significant volatility clustering in Ghana stock market returns has support in the empirical literature. For example, Njimanted (2012) investigate volatility and efficiency of stock returns in African stock markets including, Egypt, Kenya, Nigeria, South Africa, and Ghana. The results from their GARCH-M model provide support for volatility clustering in the markets evaluated. The evidence of significant volatility clustering in South African stock market returns has been documented by earlier studies. Makhwiting, Lesaoana and Sigauke (2012) evaluated Johannesburg Stock Exchange using ARMA-GARCH models for the period starting from 2002 to 2010. The findings show amongst others that South Africa stock market returns exhibit volatility clustering. Our results also agree with the findings of Mwamba, Thaba and Uwilingiye (2014) and Botha and King (2014) who also document evidence of volatility clustering in South Africa stock market returns.

Visual inspection of Table 3 also shows that the non-negativity constraint of the GARCH $(1,1)$ model is not in doubt for the models estimated.
This suggests that models are robust. More so, the diagnostic tests results presented in the Panel $B$ of Table 38 show that the Ljung-box Q-statistic for residuals of the Sub-Sahara African stock markets returns are not significant, indicating that there is no serial correlation in the standardized residuals. The ARCH-LM result also indicates that the null hypothesis of no heteroscedasticity in the squared residuals is accepted at the 5\% significance level. Hence supporting adequacy of the GARCH $(1,1)$ model for policy-making.

\section{CONCLUSIONS AND SUGESTION}

This study majorly hunted for evidence of volatility clustering and persistence in Sub-Sahara Africa stock markets with specific reference to Nigeria, Ghana and South Africa. The financial econometric methodology applied in this study include descriptive statistics, tests for unit roots and univariate GARCH $(1,1)$ model. Descriptive statistics calculated to evaluate the mean; symmetry and distribution of the stock markets returns provide insightful information. The mean monthly returns are positive for all the stock markets but the South Africa stock market generates more returns than Nigeria and Ghana within the study period. Skewness coefficients show that the stock returns distributions of all Sub-Sahara Africa stock markets are negatively skewed. Excess kurtosis is positive for all the stock markets returns. These show that all the markets returns are peaked. The Jarque-Bera statistics indicate the stock markets' series are not normally distributed. Unit roots tests to verify the nature of stationarity of the Sub-Sahara Africa stock markets series indicate that the Sub-Sahara Africa stock markets series are integrated of order one. The results of GARCH $(1,1)$ model estimated to examine the nature of volatility clustering and persistence provide evidence of volatility clustering and persistence in the Sub-Sahara Africa stock market returns. On the basis of the findings, the study concludes that there is volatility clustering and persistence in the Sub-Sahara Africa stock market returns.

Based on the conclusions from this study, we recommend that Sub-Sahara Africa portfolio managers watch movements in stock market volatility as part of their portfolio management strategy and formulate cushion policies to mitigate effects of volatility shocks from the stock markets. In addition, Sub-Sahara Africa stock market authorities should also enlighten retail investors on the behaviour of stock market volatility in their respective stock markets so as not to discourage their partici- 
pation in stock trading as a result of stock returns volatility. This is necessary because evidence of volatility clustering provide basis for investors adjust their portfolio accordingly

\section{REFERENCES}

Ahmed E.M.A. \& Suliman Z.S. (2011). Modeling Stock Market Volatility Using GARCH Models eEvidence from Sudan. International Journal of Business and Social Science 2(23) December: 114-128.

Anjikwi, A \& Danjuma, J. (2018). Analysis of Nigeria Stock Market Using Bayesian Approach in Stochastic Volatility Model (2012 - 2016). International Journal of Statistics and Applications, 8(2), 53-58.

Bollerslev, T. (1986). A Generalized Autoregressive Conditional Heteroscedasticity. Journal of Econometrics, 31, 307-327.

Botha, F. \& King, D. (2014). Modelling stock return Volatility Dynamics in Selected African Markets. Economic Research Southern Africa working paper 410, by the National Treasury of South Africa.

Brook, C. \& Burke, S.P. (2003). Information criteria for GARCH Model Selection: An Application to High Frequency Data. European Journal of Finance, 9(6): 557-580.

Chowdhury, S.; Mollik, A. \& Akhter, M. (2006). Does Predicted Macroeconomic Volatility Influence Stock Market Volatility? Evidence from the Bangladesh Capital Market. Department of Finance and Banking, University of Rajshahi Working Paper.

Dickey, D. A. \& Fuller, W. A. (1981). Likelihood Ratio Statistics for Autoregressive Time Series with a Unit Root. Econometrica, 49 (4).

Emenike, K. O. (2010). Modelling stock returns volatility in Nigeria using GARCH models. African Journal of Management and Administration, 3(1): 8-15.

Emenike, K. O. (2016). Comparative Analysis of bureaux de Change and Official Exchange rates Volatility in Nigeria. Intellectual Economics, 10(1): 28-37.

Emenike, K. O. \& Aleke, S. F. (2012). Modeling Asymmetric Volatility in the Nigerian Stock Exchange. European Journal of Business and Management, 4(12): 52-59.

Emenike, K. O. \& Ani, W. U. (2014). Volatility of the Banking Sector Stock Returns in Nigeria. Ruhuna Journal of Management and Finance, 1(1): 73-82.
Enders, W. (2004). Applied Econometric Time Series $\left(2^{\text {nd }} E d\right.$.). Singapore: John Wiley \& Sons (ASIA) Pte Ltd.

Engle, R. F. (1982). Autoregressive Conditional Heteroscedasticity with Estimates of the Variance of the United Kingdom Inflation. Econometrics, 50: 987-1008.

Engle, R.F., \& Paton A. J. (2001). What Good is a Volatility Model? Retrieved from http:// papers.ssrn.com/sol3/papers.cfm?ab stract_id=1296430.

Gujarati, D. N. (2003). Basic Econometrics (4th Ed.). Delhi: McGraw Hill Inc.

Makhwiting, M.R., Lesaoana, M. \& Sigauke, C. (2012). Modelling Volatility and Financial Market Risk of Shares on the Johannesburg stock exchange. African Journal of Business Management, 6(27): 8065-8070.

Mwamba, J.M., Thaba, L. \& Uwilingiye, J. (2014) Modelling the Short-term Interest Rate with Stochastic Differential Equation in Continuous time: linear and nonlinear models. MPRA Munich personal repec archive, Retrieved from http://mpra.ub.unimuenchen.de/64386.

Nelson, D. (1991). Conditional heteroscedasticity in asset returns: A new approach. Econometrica, 59(2): 347-370.

Okpara, G.C. \& Nwezeaku, N.C. (2009). Idiosyncratic Risk and the Cross-Section of Expected Stock Returns: Evidence from Nigeria. European Journal of Economics, Finance and Administrative Sciences, 17: 1-10.

Schwert, G. W., (1989). Why does stock market volatility change over Time? Journal of Finance, 44: 1115-1153.

Wilcox, R. R. \& Keselman, H. J. (2003). Modern Robust Data Analysis Methods: Measures of central Tendency. Psychological Methods, 8(3): 254-274. 